The Turkish Online Journal of Design, Art and Communication - TOJDAC

ISSN: 2146-5193, September 2018 Special Edition, p.1065-1073

\title{
LANGUAGE CONTACT: LEXICAL BORROWING IN SPEECH OF THE RUSSIAN GERMANS OF THE KIROV REGION
}

\author{
Olga Vladimirovna BAYKOVA \\ Vyatka State University, Russia \\ Galina Vasilyevna PORCHESKU \\ Vyatka State University, Russia \\ Vyacheslav Nikolayevich ONOSHKO \\ Vyatka State University, Russia \\ Irina Sergeevna SHISHKINA \\ Vyatka State University, Russia \\ Olga Vitalyevna SKURIKHINA \\ Vyatka State University, Russia \\ Anna Yuryevna MIRONINA \\ Vyatka State University, Russia
}

\begin{abstract}
German speech islands of the Kirov Region have a status of emigrant ones and are usually defined as disappearing dialects of the German language or specific supra-regional formations. The relevance of the study of the German speech islands of the Kirov region is explained by the general linguistic, historic linguistic, sociolinguistic significance of German dialectology which deals with the study of the development and functioning of dialects in a foreign language environment, i.e. when a separate ethno-linguistic group lives in isolation from the main ethnic community. This article analyzes lexical borrowings in the speech of the Russian Germans of the Kirov region as a form of language interaction. For a long time, German speech islands have been subjected to a strong Russian language interfering influence. The lexical borrowings, mainly from the Russian language, represent one of the ways to maintain and replenish the vocabulary of speech islands and perform various semantic and stylistic functions. The article may be of interest to researchers in the field of German dialectology and German speech islands.
\end{abstract}

Keywords: Russian Germans, Speech Islands, Russian Borrowings, Language Contact

\section{INTRODUCTION}

The Kirov region is one of the largest multinational regions of the Russian Federation which includes representatives of more than a hundred nationalities. The main ethnic groups are Russians, Tatars, Mari, Udmurts, Ukrainians, Byelorussians, Azerbaijani, Armenians, Gypsies, Chuvash, Germans, Moldovans, Komi. As a result of such multilingualism, there has developed a linguistic situation characterized by a great variety of interacting languages and their forms functioning on a relatively small territory. More than that, speech of people is, naturally, subject to social stratification which makes the process of language interaction even more complicated. Thus, the Kirov region is an interesting and important place where comprehensive linguistic and socio-cultural studies can be conducted.

The problem of the language forms is of great importance in modern linguistics. In domestic and foreign studies of recent decades, it is often stated that, despite a large number of studies devoted to 
language variation, many issues related to heterogeneity of the language continuum still remain relevant but under-researched. It especially applies to some problems associated with a multifaceted description of the language forms found in different territories and defined as relatively autonomous communication systems having their own specific elements, norms, and speakers.

Quite recently, in the late 1980s, there was an increase of academic interest in the problem of the relationship between language and the environment caused by the scientific concern over the fate of national minorities in Russia and the CIS. This resulted in an increased number of studies of history, culture, and language of these minorities. The linguistic diversity, dying and disappearing languages are the topics of numerous studies at the turn of XX and XXI centuries. The fate of such languages, their present functioning, and their future is the priority for humanity since language reveals the world philosophy; it is a system of knowledge about the world, reflected in its rules and linguistic structure. This problem is also studied within the framework of German speech islands in Russia and other CIS countries and has its own traditions: the focus is always on the inhabitants of the speech islands and their dialects (Dinges, 1925; Schirmunski, 1931; Dongauzer, 1980; Vashkau, 1994; Domashnev, 2005; Klassen, 1969; Stumpp, 1972; Auerbach, 1989; Naidič, 1997). The significance of the research in this field is quite evident, since recording an authentic linguistic worldview of the Russian Germans makes it possible to preserve it. Although, it is currently becoming extremely difficult to do it due to gradual disappearance of these dialects. Besides, a speech island is a kind of a "language laboratory" (Schirmunski, 1930) bringing about in short time the linguistic processes which developed over centuries on the way to our contemporary standard languages.

It is well-known that there are some isolated separate speech islands still existing in Russia, where speakers of various German dialects live. Their ancestors moved from Germany to Russia in the second half of XVIII - early XIX centuries. The dialects of many of such islands have been described quite comprehensively (Smirnitskaya \& Barotov, 1997; Moskalyuk, 2000; 2002; Dyatlova, 2003; Moskvina, 2006; Svetozarova, 2006; Serzhanova, 2007). However, there are also Russian German settlements which are still little known and whose dialects have scarcely been investigated. These include, for example, the former special settlements of Sozimsky and Chernigovsky of the Verkhnekamsk district of the Kirov region whose German dialects represent a unique form of the language that has evolved under certain historical and social conditions and they have been functioning in the context of intralinguistic and interlingual interaction. The German dialects of the above-mentioned settlements genealogically belong to the two main dialect groups: Low German and Upper German, however, as a result of their separation from the main ethnic group they developed their own phonetic, morphological, syntactic and lexical features determined by the internal laws of language development. At the same time, these dialects have for a long time been exposed to and are still influenced by a foreign language environment, primarily that of the Russian language, which leads to alignment and unification of the languages.

\section{HISTORICAL BACKGROUND OF THE GERMAN-RUSSIAN BILINGUALISM IN THE KIROV REGION}

In the Kirov region, the representatives of the German national minority do not live as a closed community consolidated by means of economic, cultural and linguistic relations. The Russian Germans form a small ethnic group. According to statistics, there are 1408 of them among the multinational population of the region. Although some authentic or traditional characteristics of this population are preserved, new ones have also appeared. It was mainly caused by the forced character of the resettlement process: these people were deported from Ukraine, the Volga region, and Kazakhstan during the Second World War. The traditional specificity of the way of life is still preserved to some extent in the form of habits, traditions, and everyday activities, and it has been especially manifested in the sphere of spiritual culture and understanding their national identity recently. The German Russians of the Kirov region do not live here as a more or less united community whose members are in constant contact (including the linguistic one), and they are the speakers of the Upper German and Low German idiolects.

The nature of the German-Russian bilingualism of the Russian Germans in the Kirov region is determined on the basis of the studies of Russian Germans conducted by Boni, Kirshner, Manykin, Smirnitskaya in different regions of the former Soviet Union (Smirnitskaya \& Barotov 1997; Baykova, 2011; Bukharov \& Baikova, 2016; Boni, 1990). 
According to our research, there are five consecutive transition stages from the German language to the Russian language:

1) active German monolingualism;

2) active-passive German-Russian bilingualism;

3) active German-Russian bilingualism;

4) passive-active German-Russian bilingualism;

5) active Russian monolingualism.

Having analyzed the research data, we revealed that each age group of ethnic Germans can be characterized by a certain stage of bilingualism. Thus, most of the representatives of the older age group have already passed the first two stages of bilingualism: active German monolingualism, activepassive German-Russian bilingualism. Currently, the representatives of this group are characterized by active German-Russian bilingualism, which means they are active speakers of both the German dialect and the Russian language.

For the average-aged group, the two stages of bilingualism are the stage of passive-active GermanRussian bilingualism and the stage of active Russian monolingualism. The informants who are at the stage of passive-active German-Russian bilingualism have been exposed to the German dialect since birth in the family but due to the limited spheres of application of the German language they have not had a possibility to speak it regularly and currently they can only understand the German dialect, and they can write and read German within the framework of the school curriculum. As for the Russian language, the German representatives of this age group are fluent in Russian and actively use it in all communication spheres.

The young adult group is at the stage of active Russian monolingualism. The majority of the Russian Germans of this age group does not know the German language and does not use it in communication. The representatives of the young adult group studied or study German at school, at university, or by taking a German language course. In this case, one can speak of Russian-German bilingualism, which can be characterized as an individual, non-contact, artificial, auxiliary type of bilingualism, which means that German is a foreign language for the Russian Germans of this age group; it is their nonnative or second language.

The German-Russian bilingualism is one-sided: the Germans of the Kirov region know and speak Russian, but the Russian inhabitants of these settlements do not speak German because the functions of the language systems, the area of their distribution, and the number of speakers of these languages are different. In terms of the scope of application spheres, the minority language is a monofunctional language representing the second code system, and the contacting Russian language which has the maximum social load in the public life of the Russian Germans is a widely used language functioning as the first one.

The bilingualism under study is characterized as a mass one, since all the Germans of the Kirov region speak Russian. The German-Russian bilingualism can be considered natural because the Russian Germans came to live in the Kirov region for historical reasons, they were in constant contact with the Russian language, and they learned the Russian language naturally, in the process of their working life and activities.

The German-Russian bilingualism of the Russian Germans of the region under consideration is the subordinate one: it is characterized by mixed utterances, i.e. the Russian Germans can use either their own dialect or the Russian language in accordance with a particular linguistic and extra-linguistic situation and context.

The sociolinguistic survey of the Russian Germans of the Kirov region has revealed a number of circumstances that contributed to a comparatively high degree of the linguistic assimilation of the German population in favor of the Russian language. The most important is the fact that there are no purely German settlements in the region under study. Despite the fairly large number of Russian Germans, they are one of the national minorities scattered among the multinational population. The second important circumstance is a highly diverse national composition of the Kirov region population. This fact is a consequence of the intersection of multinational migration flows of the postwar period in this region which has made the Russian language a language of interethnic communication for all ethnic groups represented, including the Germans. Another peculiarity contributing to the linguistic assimilation of ethnic Germans in the region under consideration is the 
lack of institutions supporting language competence in their native language and promoting its use in everyday life.

It should be noted that the stages of bilingualism, the spheres of use of the German and Russian languages by ethnic Germans of the Kirov region, and the choice of the native language are determined by various extralinguistic factors, in particular, socio-demographic factors such as age, education, gender of the informants, family background.

\section{LEXICAL BORROWINGS IN THE LEXICON OF THE GERMAN SPEECH ISLAND DIALECTS}

It should be noted that the Russian language plays a dominant role in communication of the Russian Germans, and the dialect as a minority language is doomed to retreat due to a powerful impact of a foreign language environment. This environment can be characterized as a complex exoglossal disbalanced linguistic situation when the dialect system of the Russian Germans is directly and indirectly influenced by the national Russian language and other dialects.

The Russian Germans alternately use their native German and non-native Russian in daily communication. The phenomenon of alternate use of the language variants representing the language repertoire of the speakers, which functionally complement each other, has long attracted interest of researchers interested in bilingualism issues. Basil Bernstein, who paid special attention to sociolinguistic issues, believed that the linguistic behavior is a function of the social structure. $\mathrm{He}$ argued that the relationship between the language and the social class was fundamental. Different social structures create different systems of language use or are reflected in them. Accordingly, he distinguished two types of socially conditioned specific language codes and language behavior: restricted (restringiert) and elaborated (elaboriert) codes (Bernstein, 1971).

According to Moskalyuk (Moskalyuk, 2000), if the verbal behavior of a monolingual speaker involves the use of different forms of the native language depending on a particular situation of verbal communication, then the speech behavior of a bilingual speaker presupposes, first and foremost, the choice of a particular language. It is well known that we can observe code switching in the speech of bilingual speakers, which is usually understood as the speaker's switching from one language to another within a single utterance (Bechert, 1991).

The code-switching results in extensive borrowing. For two hundred years, the German island dialects have been subjected to a strong interfering influence of the Russian language, and the changes resulting from interlingual contacts have taken place almost at all linguistic levels. According to the researchers of the German island dialects, two tendencies can be observed in their development: on the one hand, preservation of archaic features at different linguistic levels and, on the other, the innovation tendency (Kuksina, 1999; Moskalyuk, 2002). The speech island dialects have existed for a long time in isolation, away from the base dialect and from the German-speaking environment. So one of the ways to maintain and replenish the lexical corps is lexical borrowing, mainly from the Russian language, with the loanwords performing various semantic and stylistic functions in the dialect. Dinges, who studied the borrowings from the Russian language in the German island dialects, identifies the following reasons for this process of lexical borrowing (Dinges, 1929):

1. A word from another language is borrowed to express the emotional component of the meaning more clearly, since the word of the native language does not seem to be expressive enough: Durak! (Fool!).

2. The stylistic reasons for the use of a borrowed word, for example, if the speaker wants to comprehensively convey the facts of the foreign-language reality: Spasiv sed $d r$ Rus (Thank you, said the Russian) - Spasiv - from the Russian 'Spasibo').

3. The word of the other language can convey an ironic meaning in speech: Balvan! (Blockhead!)

4. The borrowed word is used in those cases when it, for some reason, seems more preferable, since it renders the speaker's idea more accurately in comparison with the native word: vot (well) $d s$ ha:v ęk jazax, ds ęs ręktək, eto pravilno (it's correct).

The term 'borrowing' is treated differently in the scientific literature on linguistics. Traditionally, the concept of borrowing can be understood in two ways: on the one hand, borrowings are the elements of another language brought into the other as a result of language contact, and on the other, it is a process of transition of the elements of one language into another (Linguistic Encyclopedic Dictionary 1990). As for the language situation characteristic of the dialect (speech) islands, the types of borrowings 
described by Bloomfield are of special significance; they are internal borrowings resulting from direct language contacts due to territorial or political proximity and dialectic borrowings penetrating into the literary language from dialects (Bloomfield 2002).

In Linguistics of XIX-XX centuries there was a lot of debate about the following: whether borrowings of grammatical units and structures (Whitney 1868) are possible; about mixing languages the sign of which was considered to be the borrowing of non-lexical, primarily grammatical, material; whether grammatical borrowing is only possible in the context of borrowing a whole linguistic system (Meye 1954), or only at the morphological level, not at a deeper grammatical level (Sapir 1993). Though scholars may differ as to whether or to what extent different elements of the linguistic structure are affected by language contact, there is a broad agreement following Weinreich (Weinreich 2000) that any linguistic material can be borrowed under the conditions of close language contact which is longlasting and extensive.

In this case it is important to distinguish between the phenomena of borrowing and codeswitching. The criteria in this instance are various kinds of assimilation: phonetic assimilation, that is the replacement of the Russian phonemes and/or their combinations with the phonemes or their combinations characteristic of the German dialects of the Kirov region; morphological assimilation or replacement of Russian inflexions with the corresponding dialect inflections; morpho-syntactic assimilation, that is when the words borrowed from the Russian language are used according to the syntax rules of the German dialects.

Since the Germans of the Kirov region first contacted the Russian language before their migration to the Kirov region, the lexical borrowings from the Russian language often refer to the pre-war German settlements in the Volga region, Ukraine and the Trans-Caucasian region. The speech of ethnic Germans still preserves some Russian or Ukrainian words associated with the names of fruit, vegetables, food, household utensils, etc.

For example, the names of fruit, vegetables, cereals, which were cultivated by residents of German settlements in Ukraine and in the Volga region: pəmįdo:rə ${ }^{\circ}$ bəmado:rə ${ }^{\circ}$ - tomatoes, hərpu:sə $\%$ arbu:zə ${ }^{\circ}$ - watermelons.

The names of dishes cooked in Russia and Ukraine and also used by the Germans: poršt - borsch or beet-root soup, $\check{s} t s ̌ i$ - Russian cabbage soup, varę:nikə - varenyky or dumplings.

The names of tableware and utensils: kəštro:l - a saucepan, pu:tl/butal - a large bottle.

The names related to life in pre-war colonies: kalxo:s - kolkhoz or a collective farm, kalękti:f - staff members or a team of employees, selsave:t - selsoviet or a local council.

The names of some concepts and realias related to life in the deportation areas: trudarme ${ }^{*}$ labour army, pavestkə ${ }^{\circ}$ - a summons.

These groups of loanwords denote the concepts and realias of everyday life; they have entered the lexicon of ethnic Germans and undergone certain phonetic and grammatical changes. Thus, words borrowed from the Russian language can be used as components of German compound words, as well as parts of words formed according to a German word-building patterns: flęšməšị: $n$ (meat-mincing machine), voršsort (kind of sausage), bəmədo:rnzopə (tomato soup) or trudarme (labour army). The borrowed words have adopted the German pronunciation to a greater or less degree, and in many cases, they are used according to the rules of the German morphology: an di ${ }^{\circ}$ trudarmija (to the labour army), in di $i^{\circ}$ banja' (in the bathhouse), fon i:ram kəmęndətu:rə' (from their commandant's office).

The borrowings which are used in the speech of the Russian Germans of the Kirov region can be divided into the following theme groups:

1) borrowings related to life and living conditions in pre-war colonies (kalxo:s - kolkhoz or a collective farm, kalękti:f - staff members or a team of employees, selsave:t-a local council, etc.);

2) borrowings which entered the lexicon of the Kirov Region Germans during deportation (trudarme - labour army, vysof - a summons, kamęndatura ${ }^{\circ}$ - commandant's office, etc.);

3 ) borrowings related to the relationship status of German bilinguals (main papka ${ }^{\circ}$ - my father, doška - daughter, vnušk ${ }^{\circ}$ - granddaughter, etc.);

4) borrowings related to the theme of 'dwelling' (zərę - saray in Russian or a barn, dəvã :tšsk - a sofa, pala:s - palas or a carpet, jara: $\breve{s}$ - a garage, etc.);

5) borrowings related to the theme of 'food' ( $h r e ̨ t s ̌ k a$ - buckwheat, poršt - borsch or beet-root soup, štši - Russian cabbage soup, varę:nika" - varenyky or dumplings, etc.); 
6) borrowings associated with the names of modern equipment and everyday life of ethnic Germans (təleffo: $n$ - a telephone, xələdęlnək - a fridge, dəvã : - a sofa, vã:nə ${ }^{\circ}-\mathrm{a}$ bath, these borrowings represent a direct transfer of a word from the Russian language, zborka:s - a savings bank);

7) borrowings associated with occupations or professions (kaznęts - a smith, dajarka - a milk woman, protsata:tal - a chairman).

The above-mentioned theme groups include the borrowings which were directly transferred from the Russian language into the German dialects. One can observe the so-called 'calques' and hybrid composites in speech of the Russian Germans. The tendency towards formation of complex nouns is consistent with the thesis of the nominalization tendency which has often been discussed by many scholars in the linguistic literature (Admoni, 1973; Polenz, 1985). The analysis of the lexical material compiled in the Kirov region has shown that word-building calques are rare enough compared to direct borrowings in speech of the German bilinguals. Most of these calques are nouns, compound words consisting of two components, the first of which is the stem of a noun, a verb, an adjective or an adverb: šoulo:vat - a school party, khẽ:gartə ${ }^{\circ}$ - a kindergarten, postkoštə ${ }^{\circ}$ - a mail box, o:pə 'frost Father Frost, ęsštoup - a canteen, šlo:fštoup - a bedroom, flę:jašoul - a summer school, hənštoup - a back-room, mįlaçzoup - milk soup.

As the research has shown, the borrowed words, getting into a new linguistic environment, undergo changes in accordance with the phonetic, morphological and grammatical structure of the recipient language. The borrowings can be divided into fully and partially adapted by the degree of adaptation. It should be noted that the degree of adaptation largely depends on the level of bilingualism. Adaptation of lexical borrowings takes place both at the phonetic and morphological levels, thus bringing the loanwords into proximity with the norm of the dialect.

Currently, ethnic Germans are using in their speech both phonetically adapted loanwords and phonetically partially adapted loanwords. The study results show that the degree of adaptation of the loanwords depends directly on the stage of bilingualism of a particular ethnic group. The more bilingualism is developed, the less the loanword is adapted, i.e. phonetically adapted borrowings entered the lexicon of the Russian Germans bilinguals during the period of predominant monolingualism and individual bilingualism (characteristic of the time when Russian Germans lived in the Volga region and in Ukraine): ru:bl/ru:val «Rubel» (rouble), kapika/kapi:k «Kopeke» (kopeck), kalxos «Kolchos» (collective farm).

During the period of predominant monolingualism and individual bilingualism the German immigrants used German dialects and partly literary German in their speech, without speaking or understanding the Russian language. The loanwords that penetrated the German dialects during this period underwent complete phonetic adaptation, which was a reasonable process of absorbing the Russisms into the language environment of that time. All the elements that were alien to the dialects were replaced by their own ones, close in pronunciation, i.e. a characteristic feature of the loanwords was their presence at the lexical level, which was accompanied by a substitution at the phonetic and morphological levels. Within time, the borrowed words have been adapted to the German norms so that the Russian German bilinguals no longer consider them as foreign words.

The phonetically partially-adapted words were borrowed, as a rule, during the development of subordinate bilingualism and the transition to coordinative bilingualism (during deportation of the Russian Germans to the Kirov region and their life on its territory in 1941-1956), when the speakers of the German dialects mastered the phonetic system of the Russian language to a greater degree. As a result, the loanwords were no longer adapted to a full extent at the phonetic level. During this period, any vowel in an unstressed position was subject to reduction as it happens in German dialects, i.e. there appeared the reduced [ə]: kalxos - kolkhoz (collective farm), pratseda:tl - predtsedatel (chairman), bã:nja'- banya (bathhouse), narmalnə' - normalno (wel), kato:laš - katolichesky (catholic), marka' marka (mark), zaçstaratsa - staratsya (try one's best), zəmofkə ${ }^{\circ}$ - zimovka (wintering). Similar phonetic phenomena were described by the researchers studying German island dialects in various regions of the former USSR (Altai Territory - Moskalyuk, 2002; the Urals Klassen, 1969; Sverdlovsk Region - Dongauzer, 1980; Krasnoyarsk Territory - Serzhanova, 2007).

During the period of mass coordinative bilingualism, phonetic adaptation of loanwords is, as a rule, even rarer or not observed at all: kã:m povestka (povestka - summons); elektritšestvo (elektrichestvo - 
electricity) va:r dort niç. ęç ha:v kęnə ${ }^{\circ}$ peredatša ${ }^{\circ}$ (i) k'praxt. Ęa hat gzęsa bs męarts mõ:nət $n$ dị. tjurma (tyurma-prison).

At present, it is possible to distinguish the following main adaptation types of borrowings from the Russian language at the phonetic level in the speech of the Germans of the Kirov Region:

1) complete vowel reduction at the end of words: kontor (kontora - office), kvarti:r (kvartira - flat);

2) qualitative vowel reduction at the end of words: brigada (brigada - team), mašink (mashinka - a toy car);

3) "lenis" pronunciation (devoicing) of voiced consonants in the words borrowed from Russian: toroka' (doroga - road), porš (borsch - beat root soup);

4) lenization of the consonant [s] in the middle of words: kazilka (kosilka - grass-mowing machine), pęnzi:a (pensia - pension);

5) replacement of the affricate $/ \mathrm{t} / /$ at the beginning of the word with $/ \check{s} /$ : šmadoun (chemodan suitcase), šęnək (chainik - kettle);

6) narrowing of the stressed /o/ into /jo/: špijone (shpiony - spies);

7) the palatalized $/ \mathrm{l}^{\prime} /$ is replaced with the non-palatalized /1/: tolka (tol'ko), polnitsa (bol'nitsa).

The study results suggest that the borrowed vocabulary is adapted on the morphological level through the use of the borrowed nouns with the article in accordance with their gender in the German language; the nouns are used in the plural and singular forms, they are declined, the infinitive and the past participle are formed of the verbs in accordance with the rules of the German language.

Thus, an important characteristic of the German bilingual speech at the morphological level is the use of a borrowed word with the German article in accordance with the gender of the borrowed noun: $d r$ pradsata:tal, to 'bã:nja, dr savo:t, ds apšęšita', to 'trudarmįa'.

The plural of the borrowed nouns is also formed in accordance with the norm of dialects: $t r$ kolxos $-t i$ kolxoza "der Kolchos - die Kolchose", dr pamidor-di: pamidora "die Tomate-die Tomaten".

Another characteristic feature of the Russian German speech is that the borrowed nouns are also declined according to the norm of the German dialects: von dam savot - "von dem Betrieb", von dom front - "von der Front", os dr banja - "aus dem Dampfbad", of dm davã::šak - "auf dem Sofa".

The infinitive of the borrowed verbs is formed in accordance with the norm of the dialects: galaia ${ }^{\circ}$ "spazieren", oupərị:rz- "operieren", rabo:tə" - "arbeiten", mutša - "ermorden"; the same is true about the past particple: raməntị:rt- "renoviert", gəmutšat- "ermordet"; and of the reflexive verbs: zęc prętsa - "sich rasieren", zę̧ katatsa - "Auto fahren", zęc prętatsa - "sich verstecken", zęç marętsa - "sich versöhnen".

Klassen (1969), analyzing the Russian borrowings in Low German dialects in "Russische Einflüsse auf die deutschen Mundarten im Ural (Sowjetunion)", highlights the fact that a large number of borrowings are used only occasionally, have their counterparts in German and are not assimilated. In the material under study there are some occasional borrowings: stolik (das Tischchen), dəvã:šak (das Söfchen).

As it has already been mentioned, many borrowed words denoted new concepts of the Russian reality for most German settlers. First of all, these are objects of peasant life: maina mudr hat oft kpa:ka ${ }^{\circ}$ kolobuška'(Kolobushka - a kind of a bun). However, not all cases of lexical borrowing from the Russian language can be explained by the fact that certain realities are not characteristic of the German culture and by the necessity to introduce the corresponding words. In some cases, it is based on more complicated semantic processes. In particular, we are talking about the words borrowed from Russian which have lexical counterparts with similar meaning in German: da: $k \tilde{a}: m$ dr pratsata:tal... Although the German language has some words with a similar meaning: der Chef, der Vorsitzende, der Leiter, the Russian Predsedatel is used as it helps to create the spirit of the Russian reality and means the "collective farm chairman".

There can be various reasons for lexical borrowing in such cases. We can draw a semantic parallel between the borrowed words and their equivalents denoting the same concepts in the recipient language. Compared with their German lexical counterparts, the borrowings, like synonyms, have different semantic shades. The Russian borrowings often reflect the Russian concepts or realias more clearly and accurately.

The Russian words are very often used in the speech of ethnic Germans without any morphological "processing". These do not only include the words denoting the Russian realias: pręnikə - honey cake (gęsta 'ha:mvi " pręnika 'gbaka - We baked honey cakes yesterday), but also lexemes denoting the 
concepts and realias of modern everyday life. These lexemes cannot be taken from the German literary language since the majority of Russian Germans informants do not know it, and German language literature (domestic and foreign) is practically unavailable to them. Hence, there are frequent Russian "inclusions" in the speech of ethnic Germans of the area under study. The following ones are the examples of this phenomenon:

(1) dr fa:tr ha:t pavestka' $g(a) k r i: k$ (Dad received a draft notice (povestka - in Russian)),

(2) de $r$ vysof fon mã̃ $̌$ švestr (The invitation (vyzov - in Russian) from my sister),

(3) iç ze kãu televi:zor (I don’t watch TV (televizor - in Russian)),

(4) ïmr vo:r... m:s olas nox vrutšnuju (It has always been ... you had to do it by hand (vruchnuyu in Russian)),

(5) zo: zętsza of dn dęvã:nša $k$ (so she is sitting on the sofa (divanchik - in Russian)).

It is not uncommon to include a Russian word into a German phrase in the grammatical form which corresponds to its context equivalent in the Russian sentence. This is particularly seen in cases where the Russian word is in an oblique case form:

(6) ęç ha:bə' fiə 'malšę ka ont svai dęvoškə’ (I've got four boys and two girls),

(7) via hã:m ghairat an sozamskom (We got married in Sozimsky),

(8) iç ha:bə 'g(a)arbəit an bətri:b krənofšs kom (I worked as a crane operator at the factory),

(9) də' mama ha:v jaarvęt dajarkoj (The mother worked as a dairymaid),

The function of connecting segments of speech, whether these are individual sentences or word groups, is performed by the functional words. In the speech of Russian Germans, this function is often performed by Russian conjunctions, adverbs, parenthetical words:

(10)ras mis man, dan mis man (If we need it so let it be),

(11)nu vot, iç ha:bə 'layə ' $g$ (a) arbait (So well, I've worked so long),

There are both linguistic and extra-linguistic reasons for such borrowing.

The linguistic reasons are:

1) lexical units are borrowed to denote a new notion or phenomenon (tr ukas - a decree, də ${ }^{\circ}$ pavęstka - a summons, $d \partial^{\circ}$ zamofka - hibernating area);

2) lexical units are borrowed to denote a known notion or phenomenon because the speaker does not know the native language or dialect well enough to remember the needed word (dr pasjo:laksettlement, ladna ${ }^{\circ}$ - well, good, zəka:zęvaja - to order);

3) the necessity to name a special kind of objects or concepts, to clarify or emphasize the semantic differences (dr pratsata:tal - chairman);

4) the tendency to use one borrowed word instead of a descriptive word combination in German, i.e. functioning of the economy principle (kəpəto:k - kochendes Wasser, vəkza:l - Warteraum im Bahnhof, la: $f k{ }^{\circ}-$ kleiner Kaufladen).

The extra-linguistic reasons for lexical borrowing are as follows:

1) the culture of one people influences the culture of another one (pask ${ }^{\circ}{ }^{-}$Osternkuchen, jo:lgə ${ }^{\circ}-$ Tannenbaum);

2) the expression of strong emotions as it seems to the speaker at the moment of speech that the word of the native language is not emotional enough (ox, ex, oj, ej, $n u$ - na, was du nicht sagst, maladęts Prachtkerl, dura:k - Dummkopf, karo:š, hva:tit - das genügt);

3) the desire to accurately describe the facts of life of someone else's environment (as vo:r vojna (war), męn khẽ:t... vịr lę:ba zo ${ }^{\circ} . .$. ).

\section{CONCLUSION}

The analysis of the speech behavior of German bilinguals of the Kirov region has shown that Russian borrowings have become an inherent part of the informants' lexicon: these are words related to their way of life and households, vocabulary classified as socio-political terminology and technical terminology. The main part of the loanwords is nouns; adjectives, verbs, adverbs, pronouns, conjunctions, interjections, and modal words make up quite a small portion. Such lexico-grammatical classes as particles and prepositions are not affected by foreign environment influence.

It should be noted that enrichment of the vocabulary of the native German language is mostly associated with the historically conditioned differences in the economic and cultural development of the peoples: social experience in the material and spiritual spheres is inevitably reflected in the language through borrowing of new concepts. 


\section{REFERENCES}

Admoni, V.G. (1973). Entwicklungstendenzen des deutschen Satzbaus von heute. München.

Auerbach, I. (1989). Hessen-Kassels Russlandauswanderung im 19. Jahrhundert. Hessisches Jahrbuch für Landesgeschichte, 39, 215-269.

Baykova, O.V. (2011). The nature of the German-Russian bilingualism of German bilinguals of the Kirov region. Bilingual education: theory and practice: Proceedings of the International scientific conference, April 26-28, 2011. Helsinki, Finland.

Bechert, J. (1991). Einführung in die Sprachkontaktforschung. Darmstadt

Bernstein, B. (1971). Elaborierter und restringierter Kode: Eine Skizze. Aspekte der Soziolinguistik. Frankfurt am Main.

Bloomfield L. (2002). Language. Moscow.

Boni, R. (1990). Sprachsituationsbesonderheiten beim Kontakt von Sprachsystemen verschiedenen funktionalen Werts. Das Wort. Moskau, Berlin.

Bukharov, V.M. \& Baykova, O.V. (2016). The Language of German national minority in Vyatka Region: status and perspectives. Voprosy Jazykoznanija (Topics in the study of language). Moscow, 2, $75-89$.

Dinges, G. (1925). On the Issue of Studying Dialects of the Volga Germans (Results, tasks, methods). Reprinted from Proceedings of Saratov University, Vol. 4. Saratov.

Dinges, G. (1929). About the Russian words borrowed by the Volga Germans before 1876. Saratov: Proceedings of Saratov University, 7.

Domashnev, A.I. (2005). Development of German language island dialectology in the USSR. Works on German linguistics and sociolinguistics. Saint Petersburg.

Dongauzer, V.P. (1980). Development of the sound system of a dialect in the foreign environment (based on the Frankish dialect of the German inhabitants of the city of Berezovsky, Sverdlovsk region). Leningrad.

Dyatlova, V.A. (2003). Trends in development of island dialects of the Siberia Germans under conditions of the alien and foreign language environment. Germans of Siberia: History and Culture: Proceedings of IV International Applied Research Conference. Novosibirsk.

Klassen, H. (1969). Russische Einflüße auf die deutschen Mundarten im Ural (Sowjetunion). Rostock, Wissenschaftliche Zeitschrift der Universität Rostock, 6/7, 589-594.

Kuksina, Yu.V. (1999). Russian borrowings in the vocabulary of a German language island. Linguistic research 1999. Saint Petersburg.

Linguistic Encyclopedic Dictionary. (1990). Moscow.

Meillet, A. (1954). The Comparative Method in Historical Linguistics. Moscow.

Moskalyuk, L.I. (2000). Sociolinguistic Aspects of Speech Behavior of Russian Germans in Conditions of Bilingualism. Barnaul.

Moskalyuk, L.I. (2002). The Present State of the German Island Dialects. Barnaul.

Moskvina, T.N. (2006). Language island semantic processes in the vocabulary of the German island dialect of the Altai Territory. Germans of Siberia: History and Culture: Proceedings of V International Applied Research Conference. Omsk.

Naidič, L. (1997). Deutsche Bauern bei St. Petersburg. Stuttgart.

Polenz, P. (1985). Deutsche Satzsemantik. Grundbegriffe des Zwischen-den-Zeilen-Lesens. Berlin.

Sapir, E. (1993). Selected writings in language and culture studies. Moscow.

Schirmunski, V.M. (1931). Processes of language mixing in the Frankish-Swabian dialects of southern Ukraine. Leningrad: Language and Literature, 7.

Serzhanova, Zh.A. (2007). Determining factors of speech behavior of ethnic Germans in a foreignlanguage environment. Krasnoyarsk.

Smirnitskaya, S.V. and Barotov M.A. (1997). German dialects of northern Tadzhikistan. Saint Petersburg.

Stumpp, K. (1972). Die Auswanderung aus Deutschland nach Russland in den Jahren 1763 bis 1862. Tübingen.

Svetozarova, N.D. (2006). Schirmunski's folklore-dialectological expeditions and his "Archive of the German folk songs". Russian Germanistics: Yearbook of the Russian Union of Germanists. Moscow, 2, 137-147.

Vashkau, N. (1994). Deportation of Russian Germans in 1941. Problems of Domestic History. Volgograd.

Weinreich, U. (2000). Languages in Contact: Findings and Problems. Blagoveshchensk.

Whitney, W. (1868). Language and the study of language. New York.

Submit Date: 10.07.2018, Acceptance Date: 22.08.2018, DOI NO: 10.7456/1080SSE/146

Research Article - This article was checked by Turnitin

Copyright $\mathbb{C}$ The Turkish Online Journal of Design, Art and Communication 